\title{
Uterine Morcellator versus Resectoscopy in the Management of Heavy Menstrual Flow in Reproductive-Age Women
}

\section{Hesham M Borg* and Ayman Shehata}

\author{
Lecturer of Obstetrics and Gynecology, Department, Faculty of Medicine, Tanta University, Egypt
}

${ }^{*}$ Corresponding author: Hesham M Borg, Lecturer of Obstetrics and Gynecology, Department, Faculty of Medicine, Tanta University, Egypt, Tel: +201064412277, Email: heshamborg@med.tanta.edu.eg

Citation: Hesham M Borg, Ayman Shehata (2016) Uterine Morcellator versus Resectoscopy in the Management of Heavy Menstrual Flow in Reproductive-Age Women. J Gynecol Res 2(1): 105

Received Date: October 10, 2016 Accepted Date: October 31, 2016 Published Date: November 01, 2016

\begin{abstract}
Background: Submucous leiomyoma and endometrial polyps are the most challenging causes of heavy menstrual flow (menorrhagia) accompanied with infertility, and other clinical issues. There are different hysteroscopic modalities for management of heavy menstrual flow caused by submucous myomas and polyps including conventional hysteroscopic resectoscopy and a novel, recent uterine hysteroscopic morcellator.

Aim: To evaluate the accuracy of uterine morcellator as a novel technique in the management of heavy menstrual flow and to compare it with the traditional operative resectoscope.

Material and Methods: A prospective study done at Obstetrics and Gynecology Department of Tanta University Hospital, Egypt. The study included 25 cases for morcellator versus 25 cases for resectoscope with total endometrial polyps (28 cases) and total submucous myomas (22 cases). The operating time (in minutes), total fluid distension used ( $\mathrm{ml}$ ), and total fluid deficit (ml), for morcellator and resectoscopy were collected and compared with each other, also the cervical dilatation and number of insertions and histopathologic diagnosis were recorded.

Results: There was a significant reduction in operative time in Morcellator group with mean of $8.56 \pm 1.158$ (minutes) comparing with Resectoscope group with mean of $28.16 \pm 3.636$ (minutes) with significant difference between the studied groups $(\mathrm{P}=0.000)$. The mean total fluid distension used were $3374 \pm 849.47(\mathrm{ml})$ and $5203 \pm 672.44(\mathrm{ml})$ for morcellator \& resectoscope groups respectively, with significant difference between both groups, $(\mathrm{P}=0.000)$. The mean total fluid deficit was $356.80 \pm 119.49(\mathrm{ml})$ and $586.4 \pm 153.06(\mathrm{ml})$ for morcellator \& resectoscope groups, with significant difference between both groups, $(\mathrm{P}=0.000)$.

Conclusion: Uterine morcellator is a safe, faster and easier to perform and is considered the best available modality in management of endometrial polyps and submucous myomas when compared with conventional resectoscopy.
\end{abstract}

Keywords: Hysteroscopic morcellation; Leiomyoma; Endometrial polyp; Resectoscopy

\section{Introduction}

Menorrhagia, or heavy menstrual flow, is one of the greatest common complaints met by primary care doctors and gynecologists. It is defined as menstrual loss of more than $80 \mathrm{~mL}$. This translates to menses that continues for more than seven days or the use of more than 10 pads or tampons per day. It is common conditions affecting $14-25 \%$ of women of reproductive age [1]. Although heavy menstrual flow is not fatal, it can cause chronic anemia, pelvic pain and cramping. The condition also severely influences quality of life by disrupting work, social functioning and family life. The old-style primary management for heavy menstrual flow caused by submucosal myomas or endometrial polyps involved major surgical procedure, with menorrhagia responsible for almost 20 percent of U.S. hysterectomies. Between 5 and 10 percent of all U.S. women complain to their doctors about heavy menstrual flow, which affects more than 10 million annually $[2,3]$.

Heavy menstrual flow can have hormonal or non-hormonal causes. Uterine fibroids, or myomas, are a common non-hormonal cause [1]. Clinically, there are three main categories of myomas, classified according to their site in the uterus: subserosal myomas grow in the outer portion of the uterus, intramural myomas develop within the uterine wall, and submucosal myomas grow just below the lining of the uterine cavity and close to the endometrial cavity. This last group of myomas, the submucosal, that have the most effect on heavy menstrual flow [4,5]. Because of their location on the endometrium, these myomas place pressure on the uterine lining that builds with each menstrual cycle. This, in turn, can cause heavy bleeding. Even very small submucosal myomas may cause very heavy bleeding [4,5]. Myomas in the submucosal location specifically may cause abnormal uterine bleeding or 
subfertility, and are agreeable to hysteroscopic removal. The European Society of Gynecological Endoscopy (ESGE) classifies submucosal myomas as Type 0 if the entire lesion is intracavitary, Type I if less than $50 \%$ extends into the myometrium, and Type II if greater than $50 \%$ of the myoma is intramyometrial. A correlation has been found between the depth of myometrial involvement and rate of complete resection at the time of hysteroscopy; Type II myomas have the lowest rate of complete resection at $61 \%$ to $83 \%$ [6,7]. Large fibroid size may also be associated with risk of recurrence or incomplete resection, with fibroids larger than 3 to $4 \mathrm{~cm}$ often requiring repeat procedures and myomas larger than $6 \mathrm{~cm}$ demonstrating both high recurrence and high complication rates [8-10]. To further refine the preoperative classification of submucosal myomas as a mean of predicting complete resection, Lasmer and colleagues, introduced the STEPW (size, topography, extension, penetration, wall) Classification system in 2005 and recently demonstrated significant improvement in its prognostic capabilities as compared with the older, simpler ESGE classification system [11].

Endometrial polyps are another non-hormonal cause of menorrhagia. These hyperplastic overgrowths of glands and stroma form a mushroom-like fold that projects into the uterine cavity. They can be single or multiple growths. These are one of the most common intrauterine lesions associated with abnormal bleeding symptoms; polyps are found in $10 \%$ to $40 \%$ of symptomatic women and up to $12 \%$ of asymptomatic women [12]. The great majority of symptomatic endometrial polyps occur in premenopausal women, with the highest incidence in the fifth decade of life [13]. In addition to causing bleeding symptoms such as menorrhagia, metrorrhagia, or intermenstrual spotting, endometrial polyps may be associated with subfertility or premalignant and malignant tissue changes. The use of tamoxifen and conditions such as Lynch syndrome may be associated with additional risk of developing endometrial polyps. Asymptomatic polyps less than $2 \mathrm{~cm}$ in premenopausal women may be monitored by the physician. Any lesion should be removed and sent for pathologic examination. In symptomatic patients, it has been reported that polypectomy results in improvement of symptoms in $75 \%$ to $100 \%$ of women [14].

Another pathologic entity that is agreeable to hysteroscopic elimination is retained products of conception. Tissue residual in the uterus after a pregnancy occurrence, either placental or fetal, may be a source of abnormal bleeding, pain, or infection. Pelvic ultrasonography may be beneficial to detect the retained products of conception, while results of thickened and irregular endometrium do not perfectly link with this diagnosis $[15,16]$. In some cases, hysteroscopy may produce the double advantages of a delicate diagnostic instrument and associated therapeutic interference for this postpartum complication [17].

Only a few years ago, the primary way to treat menorrhagia caused by myomas or polyps involved major surgery, including the often ineffective Dilation and Curettage (D\&C) and the very invasive hysterectomy. Complications may consist of recognized or unrecognized uterine perforation or shock, contamination, or creation of intrauterine adhesions. With regard to surgical management of endometrial polyps, a hysteroscopically directed procedure has been proved to have greater efficacy compared with the sightless approach with sharp curettage or polypectomy forceps $[18,19]$.

Conventional hysteroscopic resectoscope using a radio-frequency (RF) energy device with a wire-loop electrode can be used to eliminate large polyps and submucosal myomas, or for the handling of less common conditions such as intrauterine synechia or uterine septa. A monopolar or bipolar energy source may be used depending on surgeon liking. Select of distending media differs depending on which energy modality is used. However cautious fluid management is critical to ensure patient security in both circumstances. Monopolar electrosurgery requires a non-conducting, electrolyte-poor fluid such as glycine, sorbitol, or mannitol to avoid spreading of the electrical current. Bipolar electrosurgery may be performed with isotonic solutions such as normal saline or lactated Ringers. The nonconductive distension media carry additional risks of volume overload and electrolyte imbalances with brain damage and deaths reported secondary to hyponatremia. There is also some risk of thermal injury [20]. Resectoscope must be removed periodically so that an active suction can be inserted to clear debris from the visual field. The surgeon must pass both the hysteroscopy and resectoscope in and out of the uterine cavity numerous times to remove excised tissue. This process is very time consuming and increases the risk of puncturing the uterus [21].

Morcellator hysteroscopy is the most recent innovation in hysteroscopic treatment, delivering several advantages over conventional techniques for the removal of submucosal myomas and endometrial polyps. It is quicker, simpler, safer lesion removal. In 2005, the US Food and Drug Administration (FDA) approved the TRUCLEAR ${ }^{\mathrm{m}}$ hysteroscopic morcellator (Smith \& Nephew, Andover, MA) as the first motorized morcellator for intrauterine pathology. In 2009, the FDA approved another hysteroscopic morcellation device-the MyoSure ${ }^{\circledast}$ Tissue Removal System (Hologic, Bedford, MA). Similar to the first generation TRUCLEAR, the second generation MyoSure system depends on a suction-based, mechanical energy, rotating tubular cutter system rather than the highfrequency electrical energy historically used by resectoscopy systems to eliminate intrauterine tissue [22]. Once placed inside the uterine cavity, the device shaves off and immediately suctions out any excised tissue that might impair visibility. The ability to remove and instantly suction out tissue fragments means the hysteroscopy and morcellator are inserted only once, for initial entry. This is a huge advantage from both the physician's and the patient's point of view. For the physician, the immediate removal of tissue through the probe makes surgery much simpler to perform and requires less surgical time. The advantage for the patient is a much safer treatment. Shorter operating time means less exposure to general anesthesia and puts the patient at less risk of fluid overloading. There is also a reduced risk of puncturing the uterus from multiple entries of surgical instruments. Since the morcellator does not rely on electro-surgical techniques, the surgeon can use a saline solution for distension and irrigation instead of an electrolyte-free solution. This minimizes the risk of sodium imbalance and thermal injury. Morcellator hysteroscopy is at the chief of what will become a novel, less-invasive standard of care for treating menorrhagia caused by myomas or polyps [23]. 


\section{Patients and Methods}

\section{Study design}

A Prospective randomized controlled study using new hysteroscopic morcellator and conventional hysteroscopic resectoscopy for treating of menorrhagia (endometrial polyps, fibroid) from January, 1, 2015 to June, 30, 2016.

\section{Study settings and patients}

The study done at Obstetrics and Gynecology Department of Tanta University Educational Hospital, Egypt. The study included 50 patients allocated randomly using sealed envelopes [ 25 patients undergone hysteroscopic morcellator versus 25 patients's undergone conventional hysteroscopic resectoscopy]. Patients aged from 18-45 years suffering from heavy menstrual flow, dysmenorrhea or infertility with total number for endometrial polyps (28 cases) and submucous myomas ( 22 cases) previously diagnosed by $4 \mathrm{D}$ ultrasound.

Inclusion criteria: patients with endometrial polyps and patients with submucous myoma type 0, and type I and myoma less than $30 \mathrm{~mm}$ in diameter according to STEPW Classification, and an indication for removal (abnormal uterine bleeding, dysmenorrhea, infertility).

Exclusion criteria: were type II submucous myoma, suspicion of malignancy before surgery and contraindications for hysteroscopic surgery.

\section{Patient preparation}

All procedure were done in an inpatient setting under general anesthesia and all patients were received IV broad-spectrum

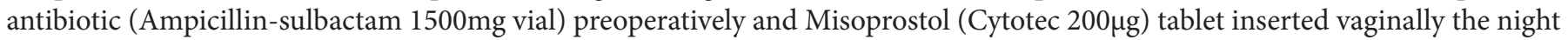
before surgery as a preoperative cervical preparation for resectoscope group which need cervical dilatation.

\section{Instrumentations}

Patients were treated with an Intrauterine BIGATTI Shaver (IBS) (Storz, GERMANY) as Morcellator and conventional hysteroscopic resectoscopy (Circon ACMY, USA). The Intrauterine BIGATTI Shaver (IBS) consist of a 6 angled telescope with an integrated sheath and working channel in which a rigid shaver system is inserted. The outer diameter of the sheath is $24 \mathrm{~F}$ ( $8 \mathrm{~mm}$ ). The rigid shaver system consists of two hollow and reusable tubes (straight, sterilizable, double serrated cutting edge, rectangular cutting window, diameter $4 \mathrm{~mm}$, length $32 \mathrm{~cm}$ ) that fit into each other. The inner tube oscillates within the outer tube and is connected to a handpiece (DRILLCUT-X II GYN) and a motor control unit (UNIDRIVE S III) as well as double roller pumps (HYSTEROMAT E.A.S.I.) which is activated by one-pedal footswitch. The footswitch simultaneously activates the movement of the shaver tip and aspiration of the double roller pump to allow continuous suction and irrigation fluid and tissue through the hollow shaver blade during procedure. Hysteroscopic morcellator (IBS, Storz, Germany) use normal saline for distension and irrigation. The conventional hysteroscopic resectoscopy (Circon ACMY, USA) equipped with a wire-loop electrode using an electro-surgical technique and use (Glycine) electrolyte-free solutions for distension and irrigation.

\section{Methods}

The operating time (in minutes), total fluid distension used ( $\mathrm{ml}$ ), and total fluid deficit ( $\mathrm{ml}$ ), for morcellator and resectoscopy were collected and compared with each other, also the cervical dilatation and number of insertions were recorded. The specimens from morcellator and resectoscope were collected for histopathologic diagnosis.

\section{Ethical considerations}

Before starting the study, an approval from The Ethical Committee of Faculty of Medicine, Tanta University was obtained. All aspects of this study were completely explained for all the participant patients and a written informed consent was taken from them before starting the operation and confidentiality and security were guaranteed.

\section{Statistical analysis}

Statistical analysis was done using SPSS program, version 20. Percentages, and $\chi^{2}$ (chi square) test are used for qualitative data. Mean \pm SD (Standard Deviation), t-test and ANOVA test used for quantitative data. $\mathrm{P}<0.05$ is considered significant.

\section{Results}

The age of the studied patients of the Morcellator group ranged between 23 and 35 years with their mean age (27.72 \pm 0.737$)$ compared with the age of the Resectoscope group which was ranged between 22 to 34 years and mean age was $28.44 \pm 3.163$ with no significant difference between both groups $(\mathrm{P}=0.439)$ (Table 1$)$.

There was no significant difference between both studied groups regarding gravidity and parity $(\mathrm{P}=0.150)$ and $(\mathrm{P}=0.721)$ 
respectively, with the mean number of gravidity among Morcellator group and Resectoscope group were $3.04 \pm 0.538$ and 3.36 \pm 0.952 respectively and mean number of parity among Morcellator and Resectoscope groups were $1.92 \pm 0.702$ and $2.00 \pm .866$ (Table 1).

The number of abortions among Morcellator group were ranged between 0 to 2 times with the mean of $1.160 \pm 0.850$ compared with Resectoscope group whose number of abortions ranged between 0 to 3 and mean $1.320 \pm 0.802$ and no significant difference occurred between both groups $(\mathrm{P}=0.497)$ (Table 1$)$.

\begin{tabular}{|c|c|c|c|c|c|}
\hline & $\begin{array}{l}\text { Morcellator } \\
\text { No. }=25\end{array}$ & $\begin{array}{l}\text { Resectoscope } \\
\text { No. }=25\end{array}$ & $\begin{array}{c}\text { Total } \\
\text { No. }=\mathbf{5 0}\end{array}$ & $\begin{array}{c}\text { Test of } \\
\text { significance }\end{array}$ & $\mathbf{P}$ \\
\hline $\begin{array}{c}\text { Age/years } \\
\text { Minimum-maximum } \\
\text { Mean } \pm \text { SD }\end{array}$ & $\begin{array}{c}23-35 \\
27.72 \pm 3.361\end{array}$ & $\begin{array}{c}22-34 \\
28.440 \pm 3.163\end{array}$ & $\begin{array}{c}22-35 \\
28.08 \pm 3.25\end{array}$ & t 0.780 & $(0.439)$ \\
\hline $\begin{array}{c}\text { Gravidity } \\
\text { Minimum-maximum } \\
\text { Mean } \pm \text { SD }\end{array}$ & $\begin{array}{c}2-4 \\
3.04 \pm .538\end{array}$ & $\begin{array}{c}2-5 \\
3.36 \pm .952\end{array}$ & $\begin{array}{c}2-5 \\
3.20 \pm .782\end{array}$ & t 1.463 & $(0.150)$ \\
\hline $\begin{array}{c}\text { Parity } \\
\text { Minimum-maximum } \\
\text { Mean } \pm \text { SD }\end{array}$ & $\begin{array}{c}1-3 \\
1.92 \pm .702\end{array}$ & $\begin{array}{c}1-4 \\
2.00 \pm .866\end{array}$ & $\begin{array}{c}1-4 \\
1.96 \pm .781\end{array}$ & t 0.359 & $(0.721)$ \\
\hline $\begin{array}{c}\text { Abortion } \\
\text { Minimum-maximum } \\
\text { Mean } \pm \text { SD }\end{array}$ & $\begin{array}{c}0-2 \\
1.160 \pm .850\end{array}$ & $\begin{array}{c}0-3 \\
1.320 \pm .802\end{array}$ & $\begin{array}{c}0-3 \\
1.240 \pm .822\end{array}$ & t 0.684 & $(0.497)$ \\
\hline
\end{tabular}

Reviewing the operative details, there was a significant reduction in operative time in Morcellator group with range of 7-11 (minutes) and mean of $8.56 \pm 1.158$ (minutes) while operative time in Resectoscope group ranged between 22-35 (minutes) with mean of $28.16 \pm 3.636$ (minutes) with significant difference between the studied groups $(\mathrm{P}=0.000)$ (Table 2).

Cervical dilatation was not done to all cases of Morcellator group whereas, it was done for all cases of Resectoscope, with significant difference between the studied groups $(\mathrm{P}=0.000)$ (Table 2$)$.

The total fluid distension used were 2210-4810 (ml) and 4100-6100 (ml) with mean of $3374 \pm 849.47(\mathrm{ml})$ and $5203 \pm 672.44$ $(\mathrm{ml})$ for morcellator \& resectoscope groups respectively, with significant difference between both groups, $(\mathrm{P}=0.000)$. The total fluid deficit was 210-610 (ml) and 410-860 (ml) with mean of $356.80 \pm 119.49(\mathrm{ml})$ and $586.4 \pm 153.06$ (ml) for morcellator \& resectoscope groups, with significant difference between both groups, $(\mathrm{P}=0.000)$ (Table 2$)$.

As regard the number of insertions was 1-2 and 3-15 with mean of $1.08 \pm 0.28$ and $6.96 \pm 3.75$ for morcellator \& resectoscope groups respectively, with significant difference between both groups, $(\mathrm{P}=0.000)$ (Table 2).

Majority of the cases (94.0\%) did not need second operation. More than half of these cases (53.19\%) related to morcellator group. Whereas three cases (6\%) only need second operations all of them (100.0\%) related to Resectoscope group [cases of fibroid type I], with no significant difference between both groups $(\mathrm{P}=0.074)$ (Table 2).

Morcellator technique was used in the management of 15 cases (53.57\%) with endometrial polyp, and 10 cases of fibroid (45.45\%) [ 7 cases type 0,3 cases type I] whereas resectoscope was used in the management of 13 cases (46.43\%) with endometrial polyp, and 12 cases $(54.54 \%)$ of fibroid [ 7 cases type 0,3 cases type I] with no significant difference between both groups $(\mathrm{P}=0.568)($ Table 2$)$.

As regard diagnosis, most cases of polyps were in the morcellator group [15 cases (53.57\%)] while most patients of fibroid were in resectoscopy group [12 cases $(54.55 \%)]$. The total number of fibroids treated in this study was [22 cases (44.0\%)] while polyps was detected in $[28$ cases $(56.0 \%)]$ (Table 2$)$.

Histopathological examination of studied cases show that 22 cases (44.0\%) were leiomyoma, 17 cases (34.0\%) were mucous polyp, and 11 cases $(22.0 \%)$ were endometrial polyp, with no significant difference between studied cases $(\mathrm{P}=0.670)($ Table 2$)$.

The operative time was a significant reduction in operative time in morcellator group when removing polyps and submucous myomas. The mean operative time for polyps in morcellator and resectoscope was $(8.13 \pm 0.88 \mathrm{~min}$ vs. $24.50 \pm 2.17 \mathrm{~min})$ respectively whereas operative time for myomas was, $(9.33 \pm 1.22 \mathrm{~min}$ vs. $29.32 \pm 3.23 \mathrm{~min})$ respectively.

On using Morcellator and Resectoscope in the management of endometrial polyps and fibroids it was found that, there was a significant difference between them regarding mean operation time $(\mathrm{F}=320.289$ and $\mathrm{P}=0.000)$. Besides this difference is significant between each maneuver and the other except that there was no significant difference between Morcellator with polyp and with fibroid regarding operation time, (Post $\mathrm{Hoc}=0.652$ ) with least time significantly occurred in using Morcellator in case of endometrial polyps and the highest time taken in using Resectoscope in the management of fibroid (Table 3). 


\begin{tabular}{|c|c|c|c|c|c|}
\hline & $\begin{array}{l}\text { Morcellator } \\
\text { No. }=25 \\
\text { No. }(\%)\end{array}$ & $\begin{array}{l}\text { Resectoscope } \\
\text { No. }=25 \\
\text { No. }(\%)\end{array}$ & $\begin{array}{c}\text { Total } \\
\text { No. }=\mathbf{5 0} \\
\text { N0. }(\%)\end{array}$ & $\begin{array}{c}\text { Test of } \\
\text { significance }\end{array}$ & (P) \\
\hline $\begin{array}{c}\text { Total operation time/ } \\
\text { minutes } \\
\text { Minimum-maximum } \\
\text { Mean } \pm S D\end{array}$ & $\begin{array}{c}7-11 \\
8.56 \pm 1.16\end{array}$ & $\begin{array}{c}22-35 \\
28.16 \pm 3.64\end{array}$ & $\begin{array}{c}7-35 \\
18.36 \pm 10.25\end{array}$ & $\begin{array}{c}\mathrm{t} \\
25.680\end{array}$ & $(0.000)^{*}$ \\
\hline $\begin{array}{c}\text { Cervical dilatation } \\
\text { Yes } \\
\text { no }\end{array}$ & $\begin{array}{c}0(0.0 \%) \\
25(100 \%)\end{array}$ & $\begin{array}{c}25(100.0 \%) \\
0\end{array}$ & $\begin{array}{l}25(50.0 \%) \\
25(50.0 \%)\end{array}$ & $\begin{array}{c}\mathrm{X}^{2} \\
50.0\end{array}$ & $(0.000)^{*}$ \\
\hline $\begin{array}{c}\text { Total fluid } \\
\text { distension used (ml) } \\
\text { Minimum-maximum } \\
\text { Mean } \pm \text { SD }\end{array}$ & $\begin{array}{c}2210.0-4810.0 \\
3374.0 \pm 849.47\end{array}$ & $\begin{array}{c}4100.0-6100.0 \\
5203.0 \pm 672.44\end{array}$ & $\begin{array}{c}2210.0-6100.0 \\
4288.5 \pm 1195.11\end{array}$ & $\begin{array}{c}\mathrm{T} \\
8.441\end{array}$ & $(0.000)^{*}$ \\
\hline $\begin{array}{l}\text { Total fluid deficit (ml) } \\
\text { Minimum-maximum } \\
\text { Mean } \pm \text { SD }\end{array}$ & $\begin{array}{c}210.0-610.0 \\
356.80 \pm 119.46\end{array}$ & $\begin{array}{c}410.0-860.0 \\
586.4 \pm 153.06\end{array}$ & $\begin{array}{c}210-860 \\
471.6 \pm 178.64\end{array}$ & $\begin{array}{c}\mathrm{t} \\
5.913\end{array}$ & $(0.000)^{*}$ \\
\hline $\begin{array}{c}\text { Number of insertions } \\
\text { Minimum-maximum } \\
\text { Mean } \pm S D\end{array}$ & $\begin{array}{c}1-2 \\
1.080 \pm 0.28\end{array}$ & $\begin{array}{c}3-15 \\
6.960 \pm 3.75\end{array}$ & $\begin{array}{c}1-15 \\
4.02 \pm 3.97\end{array}$ & $\begin{array}{c}\mathrm{t} \\
7.825\end{array}$ & $(0.000)^{*}$ \\
\hline $\begin{array}{c}\text { Need for second } \\
\text { operation } \\
\text { Yes } \\
\text { No }\end{array}$ & $\begin{array}{c}0(0.0 \%) \\
25(53.19 \%)\end{array}$ & $\begin{array}{c}3(100 \%) \\
22(46.81 \%)\end{array}$ & $\begin{array}{c}3(6.0 \%) \\
47(94.0 \%)\end{array}$ & $\begin{array}{c}X^{2} \\
3.192\end{array}$ & $(0.074)$ \\
\hline $\begin{array}{c}\text { Diagnosis } \\
\text { Endometrial polyps } \\
\text { Fibroids } \\
\text { Type } 0 \\
\text { Type I }\end{array}$ & $\begin{array}{l}15(53.57 \%) \\
10(45.45 \%) \\
7(53.85 \%) \\
3(33.33 \%)\end{array}$ & $\begin{array}{l}13(46.43 \%) \\
12(54.55 \%) \\
6(46.15 \%) \\
6(66.67 \%)\end{array}$ & $\begin{array}{c}28(56.0 \%) \\
22(44.0 \%) \\
13(26.0 \%) \\
9(18.0 \%)\end{array}$ & $\begin{array}{c}\mathrm{X}^{2} \\
0.3247\end{array}$ & $(0.5688)$ \\
\hline $\begin{array}{c}\text { Histo-pathological } \\
\text { report } \\
\text { Leiomyoma } \\
\text { Mucous polyp } \\
\text { Endometrial polyp }\end{array}$ & $\begin{array}{c}10(45.45 \%) \\
10(58.82 \%) \\
5(45.45 \%)\end{array}$ & $\begin{array}{l}12(54.55 \%) \\
7(41.18 \%) \\
6(54.55 \%)\end{array}$ & $\begin{array}{l}22(44.0 \%) \\
17(34.0 \%) \\
11(22.0 \%)\end{array}$ & $\begin{array}{c}\mathrm{X}^{2} \\
0.802\end{array}$ & $(0.670)$ \\
\hline
\end{tabular}

* = significant $\mathrm{t}=\mathrm{t}$ test $\quad \mathrm{x}^{2}=$ chi square

Table 2: Operative profile, diagnosis and histopathology of the studied groups

\begin{tabular}{|c|c|c|c|c|c|c|}
\hline \multirow[b]{2}{*}{ Operation time/minutes } & \multicolumn{2}{|c|}{ Morcellator } & \multicolumn{2}{|c|}{ Resectoscope } & \multirow[b]{2}{*}{$\mathbf{F}^{* *}$} & \multirow[b]{2}{*}{ (P) } \\
\hline & $\begin{array}{c}\text { With polyp } \\
\text { No. (\%) } \\
15(53.57 \%)\end{array}$ & $\begin{array}{c}\text { With fibroid } \\
\text { No. (\%) } \\
10(45.45 \%)\end{array}$ & $\begin{array}{c}\text { with polyp } \\
\text { No. }(\%) \\
13(46.43 \%)\end{array}$ & $\begin{array}{c}\text { with fibroid } \\
\text { No. (\%) } \\
12(54.55 \%)\end{array}$ & & \\
\hline Minimum-maximum & $7-10$ & $7-11$ & $22-27$ & $24-35$ & \multirow{2}{*}{320.29} & \multirow{2}{*}{$(0.000)^{*}$} \\
\hline Mean \pm SD & $8.13 \pm 0.88$ & $9.33 \pm 1.23$ & $24.50 \pm 2.17$ & $29.32 \pm 3.23$ & & \\
\hline $\begin{array}{c}\text { Post Hoc (scheffe) } \\
\text { Morcellator with polyp }\end{array}$ & & 0.652 & $0.000^{*}$ & $0.000^{*}$ & & \\
\hline Morcellator with fibroid & 0.625 & & $0.000^{*}$ & $0.000^{*}$ & & \\
\hline Resectoscope with polyp & $0.000^{*}$ & $0.000^{*}$ & & $0.001^{\star}$ & & \\
\hline Resectoscope with fibroid & $0.000^{*}$ & $0.000^{*}$ & $0.001^{*}$ & & & \\
\hline
\end{tabular}

** (one way Anova) * the mean difference is significant at the 0.05 level.

Table 3: Comparison of the operation time on using Morcellator and Resectoscope

in the management of endometrial polyp and fibroid

Regarding complications three cases among resectoscope group have fluid overloading, one case need ICU admission and two cases treated smoothly. One case among morcellator group [fibroid type I] has bleeding and treated by cauterization using monopolar loop of resectoscope.

\section{Discussion}

Menorrhagia is the medical term for abnormally heavy or prolonged menstrual periods. In some cases, the cause of heavy menstrual bleeding is unknown, but a number of conditions may cause menorrhagia as hormonal imbalance, uterine fibroids, uterine polyps, malignancy, pregnancy complications, adenomyosis, and bleeding disorders [24]. Imaging studies and other diagnostic measures may be helpful for accurate diagnosis and management of menorrhagia in premenopausal women. Pelvic ultrasonography 
especially 3D/4D modalities are of great help for intrauterine lesions as submucous myoma or polypi. Other diagnostic techniques include sonohysterography (saline-infusion sonography), endometrial biopsy and hysteroscopy [25]. Submucous leiomyomas and endometrial polypi are the most problematic causes associated with abnormal uterine bleeding, infertility, and other clinical issues. Treatment has been shown to be effective in improving fertility and success rates with assisted reproduction [26].

As regard hysteroscopic techniques used for management of intrauterine lesions there are 2 main techniques the traditional loop resectoscopy, and the new hysteroscopic morcellator. The new hysteroscopic morcellator has many advantages over the old technique as the quantity of tissue removed per minute is more, very fast reducing both fluid volume and operative time and by far reducing fluid complications. The new hysteroscopic morcellator allow for the use of smaller diameter hysteroscopes, which in turn requires less cervical dilation. The new hysteroscopic morcellator has a cutting window which serves in both cutting and suction of chips of uterine lesions. The morcellated tissue is contained and delivered through the morcellation system into a trap, or collecting pouch for complete capture and histopathologic assessment of all fragments extracted from the uterine cavity [27-30].

In this study we applied both the new hysteroscopic morcellator and resectoscopy for treating submucous myoma and polyps that commonly encountered in menorrhagia. The Patients under study was diagnosed by 4D ultrasound and randomly allocated into 2 groups. There was no significant difference between both groups in demographic data of age $(\mathrm{P}=0.439)$, and also gravidity $(\mathrm{P}=$ $0.150)$, parity $(\mathrm{P}=0.721)$ and number of previous abortions, $(\mathrm{P}=0.497)$ (Table 1$)$.

In this study, the operative time was significantly reduced in morcellator group when removing polyps and submucous myomas. The mean operative time for polyps in morcellator and resectoscope was (8.13 \pm 0.88 min vs. $24.50 \pm 2.17$ min) respectively whereas operative time for myomas was, $(9.33 \pm 1.22 \mathrm{~min}$ vs. $29.32 \pm 3.23 \mathrm{~min})$ respectively, with significant difference between both groups, $(\mathrm{P}=0.000)$ Table 3 . Cervical dilatation was not done to all cases of Morcellator group whereas, it was done for all cases of Resectoscope, with significant difference between the studied groups $(P=0.000)$. The mean total fluid distension used were $3374 \pm 849.47(\mathrm{ml})$ and $5203 \pm 672.44(\mathrm{ml})$ for morcellator \& resectoscope groups respectively, with significant difference between both groups, $(\mathrm{P}=0.000)$. The mean total fluid deficit was $356.80 \pm 119.49(\mathrm{ml})$ and $586.4 \pm 153.06$ (ml) for morcellator \& resectoscope groups, with significant difference between both groups, $(\mathrm{P}=0.000)$ (Table 2$)$.

The operative time was the main item studied by Emanuel, et al. that showed a significant reduction in operative time in morcellator group when removing polyps and submucous myomas. The operative time for polyps in morcellator and resectoscope was (8.7 min vs $30.9 \mathrm{~min}$ ) respectively whereas operative time for myomas was (16.4 min vs $42.2 \mathrm{~min}$ ) respectively [31]. Miller, et al. conducted a study by the newer MyoSure device and reported average polyp morcellation times of 37 seconds and average myoma morcellation times of 6.4 minutes with a mean diameter of $31.7 \mathrm{~mm}$ [32]. Garbin, et al. also used the MyoSure device in 14 patients, with a median age of 40.5 years (28-58). The time of procedure ranged from 5 to $75 \mathrm{~min}$ with a median time at $26 \mathrm{~min}$ [33].

In a multicenter trial focused on polypectomy, compared the two modalities for removal of endometrial polyps in 121 women, and found that hysteroscopic morcellation was significantly quicker for polyp removal (a median time of $5 \frac{1}{2}$ minutes, versus 10 minutes, approximately), less painful and more acceptable to women, and more likely to completely remove the polyps ( $98 \%$ compared with $83 \%$ ). The only surgical complications in either group were vasovagal reactions, which occurred in $2 \%$ ( 1 out of 62 ) and $10 \%$ (6 out of 59) of the hysteroscopic morcellation and electrosurgical resection procedures, respectively. There was one serious adverse event, with a woman treated 2 weeks after morcellation for endomyometritis [34].

Lee, et al. conducted a 3-year retrospective study on 29 cases of submucosal fibroids that were managed by hysteroscopic surgery. Conventional hysteroscopic monopolar loop resection was performed in 14 patients and another 15 underwent hysteroscopic intrauterine morcellation with the MyoSure device. At 3-month follow-up, there was no significant difference in overall patient satisfaction $(84.6 \%$ for conventional method vs $93.3 \%$ for hysteroscopic intrauterine morcellation method, $(\mathrm{P}=0.841)$. The operating time was significantly reduced for the hysteroscopic intrauterine morcellation technique (mean, 36.6 mins vs 53.6 mins in conventional hysteroscopic monopolar loop resection; $\mathrm{P}=0.005)$, particularly in those whose fibroids were $\leq 3.0 \mathrm{~cm}$ (mean, 27.6 mins vs 53.4 mins; $\mathrm{P}=0.019$ ) [35].

A recent study showed that this new method cuts average operating time in half [35]. For myomas, the mean morcellator operating time was 16.4 minutes compared to 42.2 minutes for resectoscopy. For polyps, mean morcellator time was 8.7 minutes compared with 30.9 minutes for Resectoscopy [36].

In this study, the number of insertions and entrance to uterine cavity was 1-2 and 3-15 with mean of $1.08 \pm 0.28$ and $6.96 \pm 3.75$ for morcellator \& resectoscope groups respectively, with significant difference between both groups, $(\mathrm{P}=0.000)($ Table 2$)$. As regard the need for second setting operation three cases (6\%) among Resectoscope group [cases of fibroid type I] whereas most of patients who did not need for second operation were among Morcellator group (94.0\%), with no significant difference between both groups $(\mathrm{P}=0.074)$ (Table 2).

In another study conducted on 60 patients with intrauterine pathology consisting of either a polyp or submucous myomas smaller than $30 \mathrm{~mm}$ by van Dongen, et al. who randomly allocated patients into 2 groups either hysteroscopic morcellation or loop-electrode resection. The operative time in morcellation group and resectoscopy group was (17 $\mathrm{min}$ vs $10.6 \mathrm{~min} ; P=.008)$ 
respectively [32]. In the same study there was reduction in distention media used in morcellation group and resectoscopy group (5050 mL vs $3413 \mathrm{~mL} ; P=.041$ ) respectively. Dongen, et al. also demonstrated a marked reduction in the number of insertions and reinsertions of the hysteroscopy to remove chips when the morcellator was used [37].

Histopathological examination of studied cases show that 22 cases $(44.0 \%)$ were leiomyoma, 17 cases (34.0\%) were mucous polyp, and 11 cases $(22.0 \%)$ were endometrial polyp, with no significant difference between studied cases $(\mathrm{P}=0.670)($ Table 2$)$.

When a resectoscope is used, the surgeon must rely on electrolyte-free solutions for distension and irrigation. These solutions have been recognized to cause sodium imbalances and liquid overfilling. There is also some risk of thermal injury. The treatment of menorrhagia caused by submucosal myomas or endometrial polyps was done by new method which is morcellator hysteroscopy. The morcellator shortens the operating time through rapidly eliminating tissue, which decreases the patient's exposure to anesthesia and hazard of liquid excess. The major advantages were ease of removal of tissue fragments through the instrument and the use of saline solution instead of electrolyte-free solutions used in monopolar high-frequency ordinary resectoscopy. The uses of nonelectrosurgical technique with morcellator was to avoid the danger of thermal harm and diminish the risk of sodium inequity, and lastly requires only a single entry of surgical instruments, dropping the danger of piercing the uterus.

\section{Conclusion}

Hysteroscopic morcellation is proving to be a safe and effective tool for performing myomectomy and addressing problems of infertility and abnormal uterine bleeding. It is faster and easier to perform with fewer fluid-related complications, and has shorter learning curve when compared with conventional resectoscopy. Uterine morcellator provides the best available modality for management of endometrial polyps and submucous myomas.

\section{Reference}

1. Whitaker L, Critchley HO (2016) Abnormal uterine bleeding. Best Pract Res Clin Obstet Gynaecol 34: 54-65.

2. Justin Clark T, MacKinnon Cooper NA (2016) Heavy menstrual bleeding. Womens Health (Lond) 12: 1.

3. Donnez J, Dolmans MM (2016) Uterine fibroid management: from the present to the future. Hum Reprod Update.

4. Committee on Practice Bulletins-Gynecology (2012) Practice bulletin no. 128: diagnosis of abnormal uterine bleeding in reproductive-aged women. Obstet Gynecol 120: 197-206.

5. American Association of Gynecologic Laparoscopists (AAGL): Advancing Minimally Invasive Gynecology Worldwide (2012) AAGL practice report: practice guidelines for the diagnosis and management of submucous leiomyomas. J Minim Invasive Gynecol 19: 152-71.

6. Wang H, Zhao J, Li X, Li P, Lu C, et al. (2016) The indication and curative effect of hysteroscopic and laparoscopic myomectomy for type II submucous myomas. BMC Surg 16: 9.

7. Van Dongen H, Emanuel MH, Smeets MJ, et al. (2006) Follow-up after incomplete hysteroscopic removal of uterine fibroids. Acta Obstet Gynecol Scand 85: 1463-67.

8. Inco A, Centini G, Lazzeri L, Zupi E (2015) Surgical management of abnormal uterine bleeding in fertile age women. Womens Health 11: 513-25.

9. Camanni M, Bonino L, Delpiano EM, et al. (2010) Hysteroscopic management of large symptomatic submucous uterine myomas. J Minim Invasive Gynecol 17: 59-65.

10. Zayed M, Fouda UM, Zayed SM, Elsetohy KA, Hashem AT (2015) Hysteroscopic Myomectomy of Large Submucous Myomas in a 1-Step Procedure Using Multiple Slicing Sessions Technique. J Minim Invasive Gynecol 22: 1196-202.

11. Lasmar RB, Xinmei Z, Indman PD, et al. (2011) Feasibility of a new system of classification of submucous myomas: a multicenter study. Fertil Steril 95: 2073-77.

12. Kanthi JM, Remadevi C, Sumathy S, Sharma D, Sreedhar S, Jose A (2016) Clinical Study of Endometrial Polyp and Role of Diagnostic Hysteroscopy and Blind Avulsion of Polyp. J Clin Diagn Res 10: QC01-4.

13. Wortman M. (2016) "See-and-Treat" Hysteroscopy in the Management of Endometrial Polyps. Surg Technol Int 28: 177-84.

14. Apirakviriya C, Rungruxsirivorn T, Phupong V, Wisawasukmongchol W (2016) Diagnostic accuracy of 3D-transvaginal ultrasound in detecting uterine cavity abnormalities in infertile patients as compared with hysteroscopy. Eur J Obstet Gynecol Reprod Biol 200: 24-8.

15. Capmas P, Pourcelot AG, Giral E, Fedida D, Fernandez H. (2016) Office hysteroscopy: A report of 2402 cases. J Gynecol Obstet Biol Reprod 45: 445-50.

16. Hamerlynck T, Van Vliet H, Weyers S, Schoot BC (2015) Hysteroscopic Removal of Placental Remnants: A Randomized Trial Comparing Hysteroscopic Morcellation With Cold Loop Resectoscopy. J Minim Invasive Gynecol 22: 188.

17. Di Spiezio Sardo A, Di Carlo C, Minozzi S, Spinelli M, Pistotti V, et al. (2016) Efficacy of hysteroscopy in improving reproductive outcomes of infertile couples: a systematic review and meta-analysis. Hum Reprod Update 22: 479-96.

18. Marjoribanks J, Lethaby A, Farquhar C (2016) Surgery versus medical therapy for heavy menstrual bleeding. Cochrane Database Syst Rev 19: CD003855.

19. Sawke NG, Sawke GK, Jain H (2015) Histopathology findings in patients presenting with menorrhagia: A study of 100 hysterectomy specimen. J Midlife Health 6: 160-3.

20. Calabrese S, DE Alberti D, Garuti G (2016) The use of bipolar technology in hysteroscopy. Minerva Ginecol 68: 133-42.

21. Mencaglia L, Carri G, Prasciolu C, Giunta G, Albis Florez ED, et al. (2013) Feasibility and complications in bipolar resectoscopy: preliminary experience. Minim Invasive Ther Allied Technol 22: 50-5.

22. Arnold A, Ketheeswaran A, Bhatti M, Nesbitt-Hawes E, Abbott J (2016) A Prospective Analysis of Hysteroscopic Morcellation in the Management of Intrauterine Pathologies. J Minim Invasive Gynecol 23: 435-41.

23. MyoSURE ${ }^{\text {mex }}$ Hysteroscopic Tissue Removal System 501(k) summary. Framingham, MA: Interlace Medical 30.

24. Saridogan E (2016) Surgical treatment of fibroids in heavy menstrual bleeding. Womens Health (Lond). 12: 53-62. 
25. Maybin JA, Critchley HO (2015) Menstrual physiology: implications for endometrial pathology and beyond. Hum Reprod Update 21: 748-61.

26. Khan R, Sherwani RK, Rana S, Hakim S, S Jairajpuri Z. (2016) Clinco-Pathological Patterns in Women with Dysfunctional Uterine Bleeding. Iran J Pathol 11: 20-6.

27. Pakrashi T. (2014) New hysteroscopic techniques for submucosal uterine fibroids. Curr Opin Obstet Gynecol. 26: 308-13.

28. AAGL Advancing Minimally Invasive Gynecology Worldwide, Munro MG, Storz K, Abbott JA, Falcone T, et al. (2013) AAGL Practice Report: Practice Guidelines for the Management of Hysteroscopic Distending Media: (Replaces Hysteroscopic Fluid Monitoring Guidelines. J Minim Invasive Gynecol 20 : 137-48.

29. Joseph S. Sanfilippo (2014) Hysteroscopic morcellation - a very different entity. Ob Gyn News.

30. Bhagavath B, Benjamin A (2015) Minimally Invasive Gynecologic Surgery for Benign Conditions: Progress and Challenges. Obstet Gynecol Surv 70: 656-66.

31. Emanuel MH, Wamsteker K (2005) The Intra Uterine Morcellator: a new hysteroscopic operating technique to remove intrauterine polyps and myomas. J Minim Invasive Gynecol 12: 62-66.

32. Miller C, Glazerman L, Roy K, Lukes A (2009) Clinical evaluation of a new hysteroscopic morcellator retrospective case review. J Med 2: $163-166$.

33. Garbin O, Schwartz L (2014) [New in hysteroscopy: hysteroscopic morcellators]. Gynecol Obstet Fertil 42: 872-6.

34. Smith PP, Middleton LJ, Connor M, Clark TJ (2014) Hysteroscopic morcellation compared with electrical resection of endometrial polyps: a randomized controlled trial. Obstet Gynecol 123: 745-51.

35. Lee MM, Matsuzono T (2016) Hysteroscopic intrauterine morcellation of submucosal fibroids: preliminary results in Hong Kong and comparisons with conventional hysteroscopic monopolar loop resection. Hong Kong Med J 22: 56-61.

36. Closon F, Tulandi T (2015) Future research and developments in hysteroscopy. Best Pract Res Clin Obstet Gynaecol 29: 994-1000.

37. van Dongen H, Emanuel MH, Wolterbeek R, Trimbos JB, Jansen FW (2008) Hysteroscopic morcellator for removal of intrauterine polyps and myomas: a randomized controlled pilot study among residents in training. J Minim Invasive Gynecol 15: 466-471.

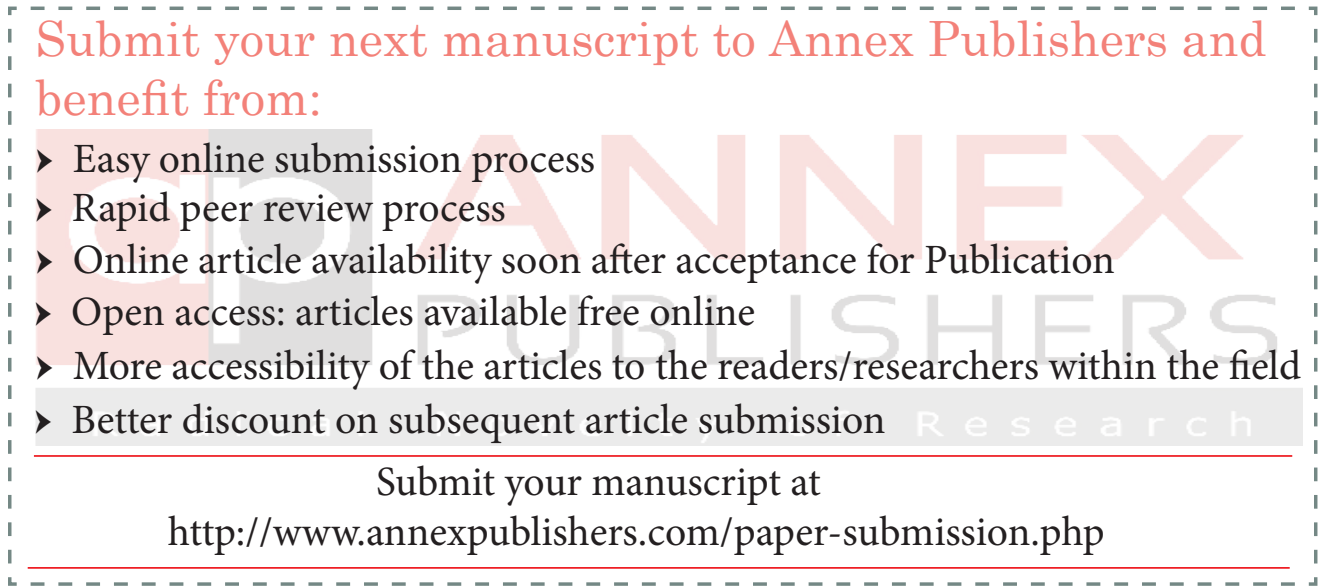

